195

$10^{-} 73$

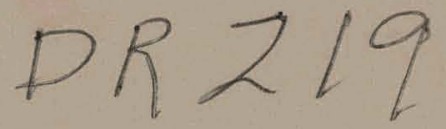

RFP-2016

June 8, 1973

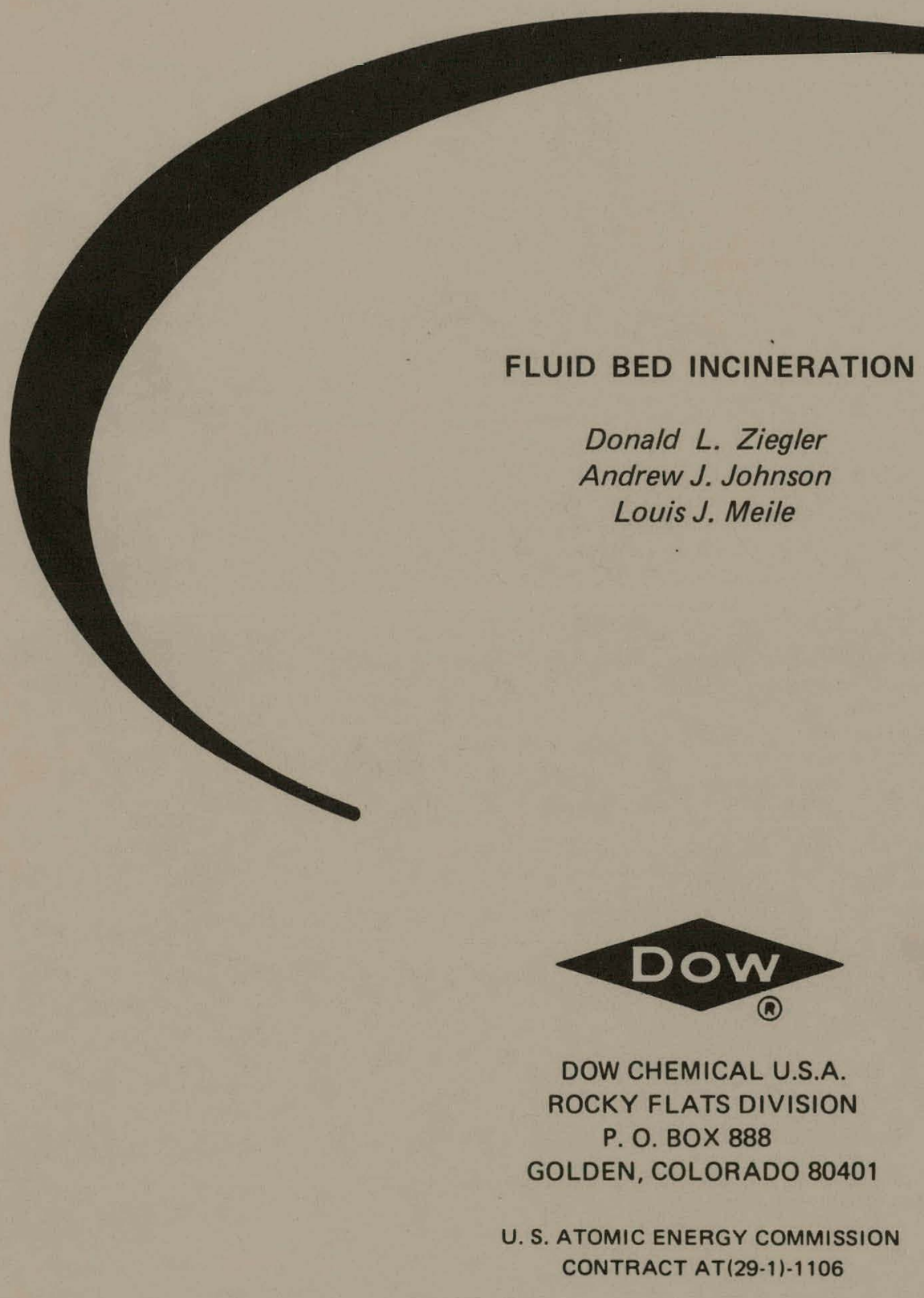




\section{DISCLAIMER}

This report was prepared as an account of work sponsored by an agency of the United States Government. Neither the United States Government nor any agency Thereof, nor any of their employees, makes any warranty, express or implied, or assumes any legal liability or responsibility for the accuracy, completeness, or usefulness of any information, apparatus, product, or process disclosed, or represents that its use would not infringe privately owned rights. Reference herein to any specific commercial product, process, or service by trade name, trademark, manufacturer, or otherwise does not necessarily constitute or imply its endorsement, recommendation, or favoring by the United States Government or any agency thereof. The views and opinions of authors expressed herein do not necessarily state or reflect those of the United States Government or any agency thereof. 


\section{DISCLAIMER}

Portions of this document may be illegible in electronic image products. Images are produced from the best available original document. 


\section{LEGAL NOTICE}

This report was prepared as an account of work sponsored by the United States Government. Neilher the United States nor the United States Atomic Energy Commission, nor any of their employees, nor any of their contractors, subcontractors, or their employees, makes any warranty, expressed or implied, or assumes any legal liability or responsibility for the accuracy, completeness or usefulness of any information, apparatus, product or process disclosed, or represents that its use would not infringe privately owned rights.

Printed in the United States of America

Available from the

National Technical Information Service

U. S. Department of Commerce

Springfield, Virginia 22151

Price: Printed Copy $\$ 4.00$ Microfiche $\$ 0.65$ 
Printed

e 8, 1973
RFP-2016

UC-4 CHEMISTRY TID-4500 - 59th Ed.

\title{
FLUID BED INCINERATION
}

\author{
Donald L. Ziegler \\ Andrew J. Johnson \\ Louis J. Meile
}

\section{CHEMISTRY RESEARCH AND DEVELOPMENT \\ Environmental Research}

\begin{abstract}
This report was prepared as an account of work spunsored by the Unid the United States nor the United States Aromic ter of Cominission, nor any of their employees, nor any of

their contractors, subcontractors, or the ir employees,

makes any warranty, express or implied, or aboumes any peyal llablity of popphainility fnr the accuracy, completeness or usefulness of any information, apparaltis, product or process disclosed, or represents that its use would not infringe privately owned tights.
\end{abstract}

$\therefore$

DOW CHEMICAL U.S.A.

ROCKY FLATS DIVISION

P. O. BOX 888

GOLDEN, COLORADO 80401

Prepared under Contract AT(29-1)-1106

for the

Albuquerque Operations Office

U. S. Atomic Energy Commission

Fivid Bod

Incineration

Waste Handling

DISTRIBUTION OF THIS DOCUMENT IS UNLIMITAPD 
RFP-2016

ii 


\section{CONTENTS}

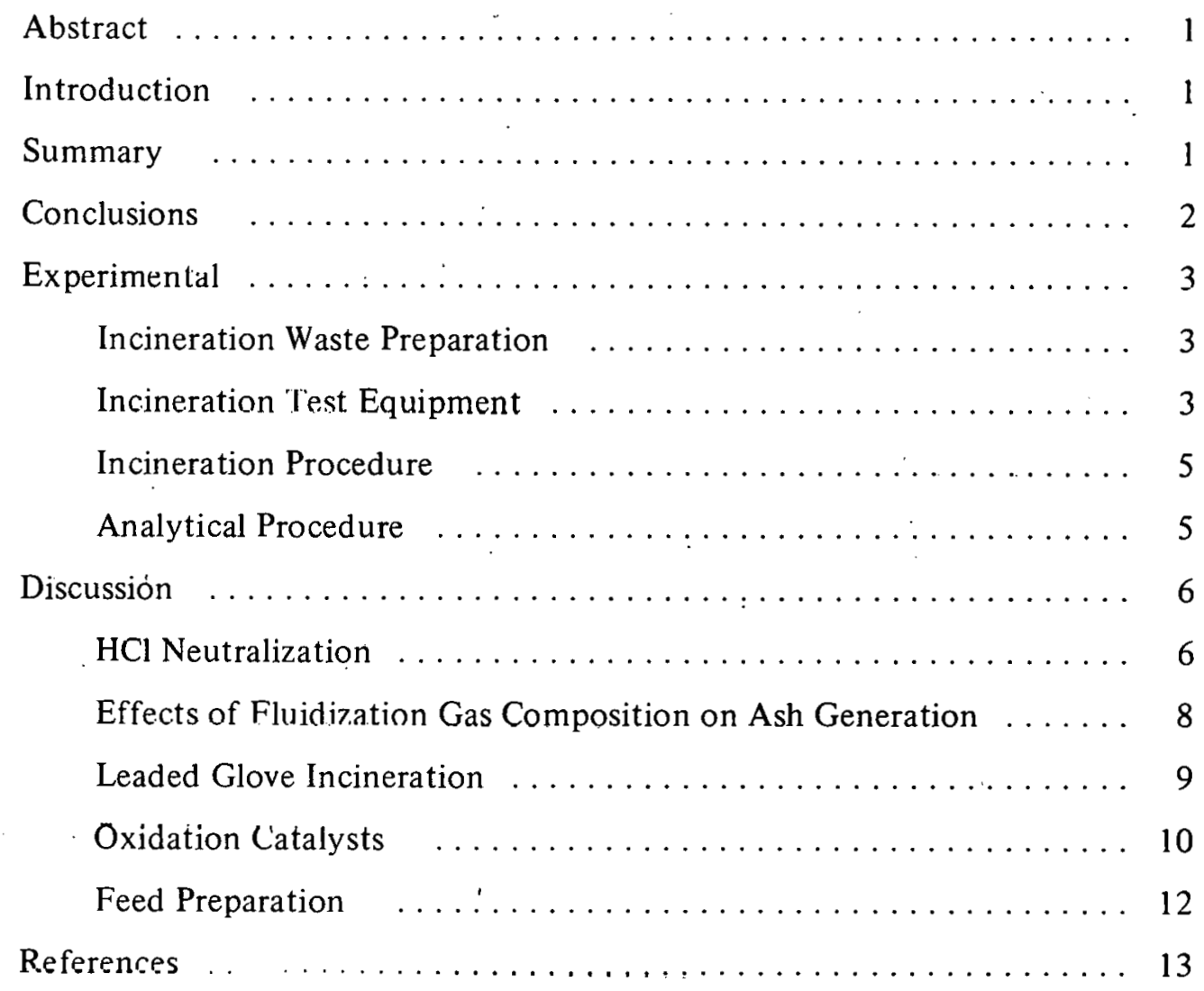




\section{ACKNOWLEDGMENTS}

The catalyst evaluation tests contained in this report were made by Carol J. Kuska, a summer student e.mployee from Temple Buell Cinllege. 


\title{
FLUID BED INCINERATION
}

\author{
Donald L. Ziegler, Andrew J. Johnson, and Louis J. Meile
}

\begin{abstract}
A fluid bed incineration process was tested on a laboratory scale for combustion of typical, plant-waste material. Sodium carbonate bed material is used for the in situ neutralization of the hydrogen chloride generated by the large amounts of polyvinyl chloride burned. Waste preparation and an evaluation of catalytic afterburning of reactor off-gases is included.
\end{abstract}

\section{INTRODUCTION}

The Rocky Flats Plant (RFP) uses incineration as a method of converting bulky combustible residues to a form that can be processed by aqueous chemistry for recovery of plutonium from the residue. The production incinerator is a stationary grate-type which operates from about 800 to $1,000^{\circ} \mathrm{C}$. The flue gas is passed through a caustic scrubbing system to remove particulate matter and acid gases, and to lower the off-gas temperature prior to HEPA filtration and release to the atmospherc. Corrosion of the incinerator and the off-gas scrubbing system has been a major problem necessitating frequent shutdowns for inaintenance and repair. The hydrogen chloride $(\mathrm{HCl})$ generated in the combustion of polyvinyl chloride (PVC) plastics is the major source of corrosive gas because PVC accounts for about $40 \%$ of the RFP waste. mixture. Another major maintenance problem has been repair of the refractory lining of the incinerator. Frequency of rebricking has been about every 6 to 12 months. By far, the most serious problem with our present incineration system is that it produces a plutonium oxide which is difficult to recover in the aqueous process presently used at Rocky Flats. The cost of incineration becomes a minor cost compared to the cost of plutonium recovery when the ash has to be leached in nitric acid as many as six times before the residue can be discarded.

A system has been proposed in which the combustible material would be pyrolyzed or combusted in a fluidized bed of sodium carbonate. The $\mathrm{HCl}$ generated from decomposition of the chloridecontaining plastics would react with the carbonate to form sodium chloride which would remain in the bed and be removed with the ash. This should minimize the concentration of acid gases in the off-gas system and should minimize corrosion of equipment. A lower operating temperature $\left(\sim 500^{\circ} \mathrm{C}\right)$ should produce a plutonium oxide that would be more soluble in the aqueous recovery process. If this type of incinerator can be coupled with a catalytic after-burner, it may be possible to eliminate the use of refractory lined equipment because the catalyst would lower the temperature required for complete combustion.

This report presents data from this project during the first three quarters of CY 72. Work covered includes testing of feed preparation equipment, testing of oxidation catalysts, and testing of a laboratory scale fluid bed incinerator. This work has been sufficient to provide design guidelines for a $10 \mathrm{lb} / \mathrm{hr}$ pilot plant fluid bed incinerator.

\section{SUMMARY}

The feasibility of a fluid bed incineration process utilizing in situ neutralization of the $\mathrm{HCl}$ generated by decomposing PVC was tested in a 2.5 -inchdiameter quartz laboratory reactor tube. The data generated on this equipment have been used to design a $10 \mathrm{lb} / \mathrm{hr}$ pilot plant incinerator. There are three major objectives of this incinerator system: (1) Provide a reactor in which lower $\left(500^{\circ} \mathrm{C}\right)$ temperature combustion is used to generate a more easily recoverable form of plutonium oxide in the ash, (2) Provide a system in which nonrefractory lined equipment can be used, thereby eliminating the maintenance problem of rebricking and the difficult problem of recovering plutonium from the used refractory, and (3) Provide a system in which the acid gas concentration in the flue gas is minimized; thereby decreasing corrosion of the incinerator and off-gas handling equipment and reducing the complexity of the flue gas scrubbing equipment. 
Open flame after-burners require about 1,000 to $1,200^{\circ} \mathrm{C}$ for complete combustion of the trace hydrocarbons in incinerator flue gas. Oxidation catalysts are satisfactory for use in the afterburner application and should reduce the afterburner temperature to between 500 and $700^{\circ} \mathrm{C}$. A chromic oxide on alumina catalyst has been shown satisfactory at a temperature about $400^{\circ} \mathrm{C}$. Molecular sieve-type materials are satisfactory catalysts for this application but would require an after-burner temperature of 500 to $600^{\circ} \mathrm{C}$.

The in situ neutralization of the $\mathrm{HCl}$ generated from the decomposition of PVC has been shown to be more than $90 \%$ effective when the waste is reacted in a bed of $\mathrm{Na}_{2} \mathrm{CO}_{3}$ and the flue gas is passed through a secondary bed of $\mathrm{Na}_{2} \mathrm{CO}_{3}$. Further neutralization can be accomplished by admixing $\mathrm{Na}_{2} \mathrm{CO}_{3}$ to the waste prior to extrusion. The extruded waste appears to be a suitable form of waste feed for the fluidized bed operation.

A reasonable mixture of the waste material is required for the pelletizing operation. Several shredders were tested and performed successfully with Rocky Flats-type waste materials. A small low-speed cutter-type of shredder appears to offer the best combination for this application with regard to product size, machine size, cost, accessibility for nuclear safety inspection, and protection of equipment from tramp metal.

Upen-flame incineration tends to be unsatisfactory for combustion of leaded gloves because of the formation of lead shot in the ash and the formation of glass by reaction of the leaded ash with refractory materials. The fluid bed incinerator appears to solve these problems by the use of lower incineration temperature $\left(500^{\circ} \mathrm{C}\right)$ and because of the ideal temperature control associated with fluid bed operation.

\section{CONCLUSIONS}

- Operation of the 2.5-inch-diameter laboratory reactor has successfully demonstrated the feasibility of fluidized bed incineration of Rocky Flats waste materials. The data generated on this scale of work have been used in the design of a $10 \mathrm{lb} / \mathrm{hr}$ fluidized bed pilot plant incinerator.

- Sodium carbonate proved to be a suitable material for in situ neutralization of the $\mathrm{HCl}$ generated by decomposition of PVC during pyrolysis or incineration.

- Catalytic oxidation was a satisfactory method for combustion of the hydrocarbons contained in the flue gas from incineration or pyrolysis of Rocky Flats-ty pe waste materials.

- Mure than $90 \%$ of the $\mathrm{HCl}$ generated by decomposition of PVC' can be neutralized with $\mathrm{Na}_{2} \mathrm{CO}_{3}$ when the waste is reacted in a fluidized bed of $\mathrm{Na}_{2} \mathrm{CO}_{3}$ and the flue gas is passed through a secondary bed of $\mathrm{Na}_{2} \mathrm{CO}_{3}$. The retention of the $\mathrm{HCl}$ can be further improved if the waste mlaterial is mixed with $\mathrm{Na}_{2} \mathrm{CO}_{3}$ and pelletized or extruded. The major advantage of removing the $\mathrm{HCl}$ from the flue gas is that it should minimize corrosion of the incinerator and offgas scrubbing equipment and should minimize the complexity of the scrubbing equipment.

- The ùse of 10 to $15 \%$ oxygen in the argon or nitrogen used for fluidization offers the best combination of bed-temperature control and low concentration of unburned carbon in the ash. The use of greater oxygen concentrations tends to allow above-bed burning which results in high bed temperatures and poor fluidization. Lower oxygen concentrations result in increased carbon concentrations in the ash.

- Shredding of waste materials probably will be required to obtain a suitable mix ture of plastic with the other waste material for the pelletizing operation. The plastic material becomes partially molten during the extrusion operation and it is . used to hold the other matcrials together in a pellet. The pelletized waste material has proved to be an acceptable feed for operation of the fluidized bed.

- Several waste shredders have been shown to do a satisfactory job of shredding Rocky Flats waste materials. Shredders tested include hammer 
nills, rubber choppers, and a low-speed knifeiype shredder. The low-speed knife-type shredder offers the best combination, for Rocky Flats type waste, of product size, machine size, cost, accessibility for nuclear safety inspection and protection of equipment from tramp metal which could be introduccd with the waste material.

- Of the catalysts tested, chromic oxide on alumina catalyst offers the best combination of resistance to $\mathrm{HCl}$ attack and minimum temperature $\left(400^{\circ} \mathrm{C}\right)$ requirements for complete combustion of hydrocarbons. Molecular sieve-type compounds are suitable catalysts for this application if higher temperatures ( 500 to $600^{\circ} \mathrm{C}$ ) are used in after-burners.

- The use of fluid bed incineration $\left(500^{\circ} \mathrm{C}\right)$ and catalytic afterburning $\left(500^{\circ} \mathrm{C}\right)$ offers the potential for an incineration system which negates the need for refractory lined equipment. Elimination of refractories removes the maintenance associated with rebricking operations and also the costly and difficult operation of recovering plutonium from used refractories. The major advantage of low temperature $\left(500^{\circ} \mathrm{C}\right)$ incineration is that a more soluble form of plutonium oxide is genterated, and therefore the cost of recovery of the plutonium from the ash is minimized.

- The fluidized bed incineration has been shown to be a suitable melhud fur combustion of leaded gloves. Open-flame incineration of leaded gloves tends to produce lead shot in the ash, and also forms lcaded glass by reaction of the ash with refractory lined equipment. In the fluid bed incinerator the lower temperature $\left(500^{\circ} \mathrm{C}\right)$ prevents the formation of the lead shot and glass.

\section{EXPERIMENTAL}

\section{Incineration Waste Preparation}

Waste materials used in the incineration experiments were pre-mixed in proportions that simulated combustible wastes generated by Rocky Flats production facilities. Table 1 shows the composition of the "Standard" waste formula that was utilized for the majority of the experiments in this study.

Table 1. Standard Waste Pellet Composition.

\begin{tabular}{|c|c|c|}
\hline Material & $\begin{array}{c}\text { Weight Percent } \\
\text { Without } \mathrm{Na}_{2} \mathrm{CO}_{3}\end{array}$ & $\begin{array}{l}\text { Weight Percent } \\
\text { With } \mathrm{Na}_{2} \mathrm{CO}_{3}\end{array}$ \\
\hline Polyvinyl Chloride & 44.50 & 30.80 \\
\hline Polyethylene & 18.90 & 13.10 \\
\hline Paper & 18.90 & 13.10 \\
\hline Surgeon Glove & 17.70 & 12.20 \\
\hline Total Combustibles & 100.00 & 69.20 \\
\hline $\mathrm{Na}_{2} \mathrm{CO}_{3}$ & 0 & 30.80 \\
\hline
\end{tabular}

The formula shown in Table 2 is similar to the formula shown in Table, except for the addition of leaded Neoprene glove material. Each waste mixture was prepared both with and without sodium carbonate for $\mathrm{HCl}$ neutralization evaluation.

Table 2. Lead Waste Pellet Composition.

\begin{tabular}{|c|c|c|}
\hline Material & $\begin{array}{l}\text { Weight Percent } \\
\text { Without } \mathrm{Na}_{2} \mathrm{CO}_{3}\end{array}$ & $\begin{array}{l}\text { Weight Percent } \\
\text { With } \mathrm{Na}_{2} \mathrm{CO}_{3}\end{array}$ \\
\hline Polyvinyl Chloride & 50.89 & 33.73 \\
\hline Polyethylenc & 21.85 & 14.48 \\
\hline Paper & 21.96 & 14.55 \\
\hline Lcaded-Neoprenc & 5.30 & 3.51 \\
\hline Total Combustibles & 100.00 & 66.27 \\
\hline $\mathrm{Na}_{2} \mathrm{CO}_{3}$ & 0 & 33.73 \\
\hline
\end{tabular}

In most incineration runs, the waste was pelletized for intimate mixing with $\mathrm{Na}_{2} \mathrm{CO}_{3}$ and ease of feeding. The materials were first manually cut into pieces no larger than one half-inch square. They were then weighed and mixed in the correct proportions. The resulting mixture was then pelletized by a batch extrusion process previously reported. ${ }^{1}$ Extrusion was carried out at a temperature of 150 to $200^{\circ} \mathrm{C}$ to avoid driving off $\mathrm{HCl}$ during the process. The size of the finished pellets was approximately one-half inch in diameter by one-inch in length.

\section{Incineration Test Equipment}

All incineration runs were made in a 2.5 -inch diameter quartz tube, approximately 32 inches in length. Several equipment arrangements were 
used to promote greater efficiency in the areas of bed fluidization, $\mathrm{HCl}$ neutralization, temperature control, tar and soot combustion, and off-gas solids separation. Precautions were taken to avoid the use of materials subject to $\mathrm{HCl}$ corrosion. Consequently, all vessels and gas transfer lines were constructed of quartz, Pyrex, or polyethylene. Three of the more typical equipment arrangements are shown in Figures 1 through 3.

Figure 1 shows an early arrangement which utilized a static bed of $\mathrm{Al}_{2} \mathrm{O}_{3}$ balls for gas preheating and a 6-inch diameter disengagement section at the top of the reaction tube. The disengagement section was replaced by a Pyrex cyclone to improve the separation of solids from the offgas stream. A sketch of this equipment is presented in Figure 2. A number of improvements in design are evident at this stage of development: namely, the cyclone separator, fluidization gas preheater, and two-stage caustic scrubbers. By this time, all gas transfer lines were constructed of Pyrex that was connected to the vessels by standard tapered glass fittings. The gas preheater was a 3,000 watt Chromalox commercial heater with piping to permit the use of air, argon, and

Figure 1. Laboratory Fluid Bed Incineration System No. 1.

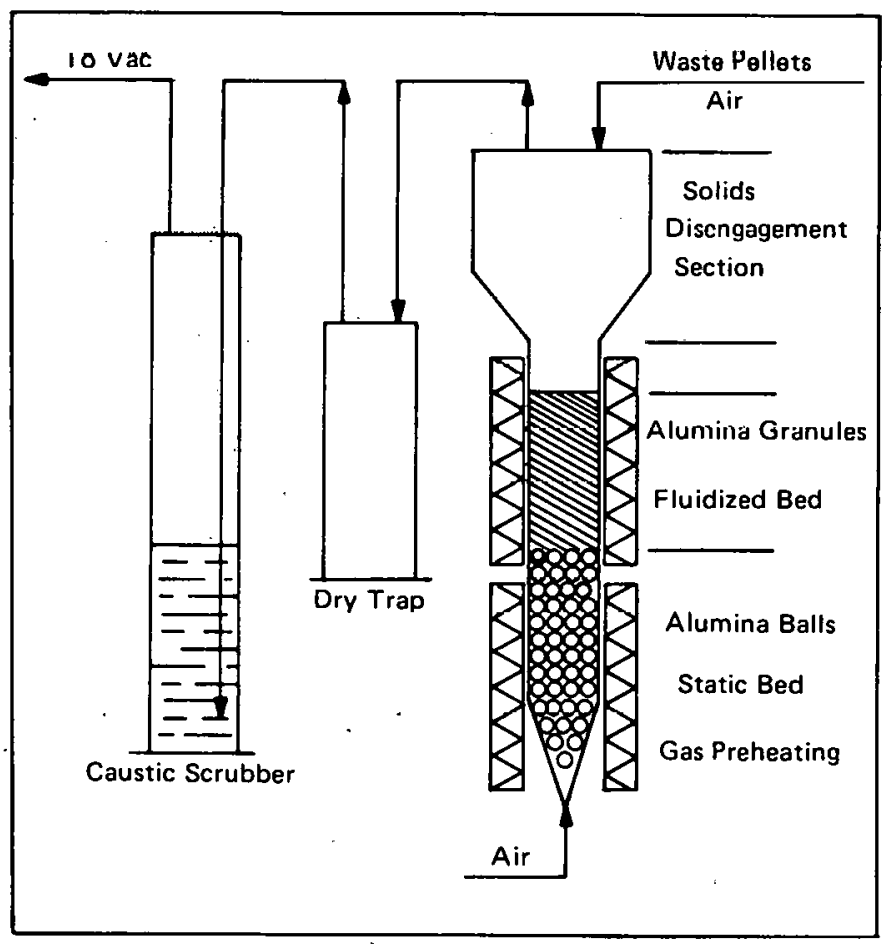

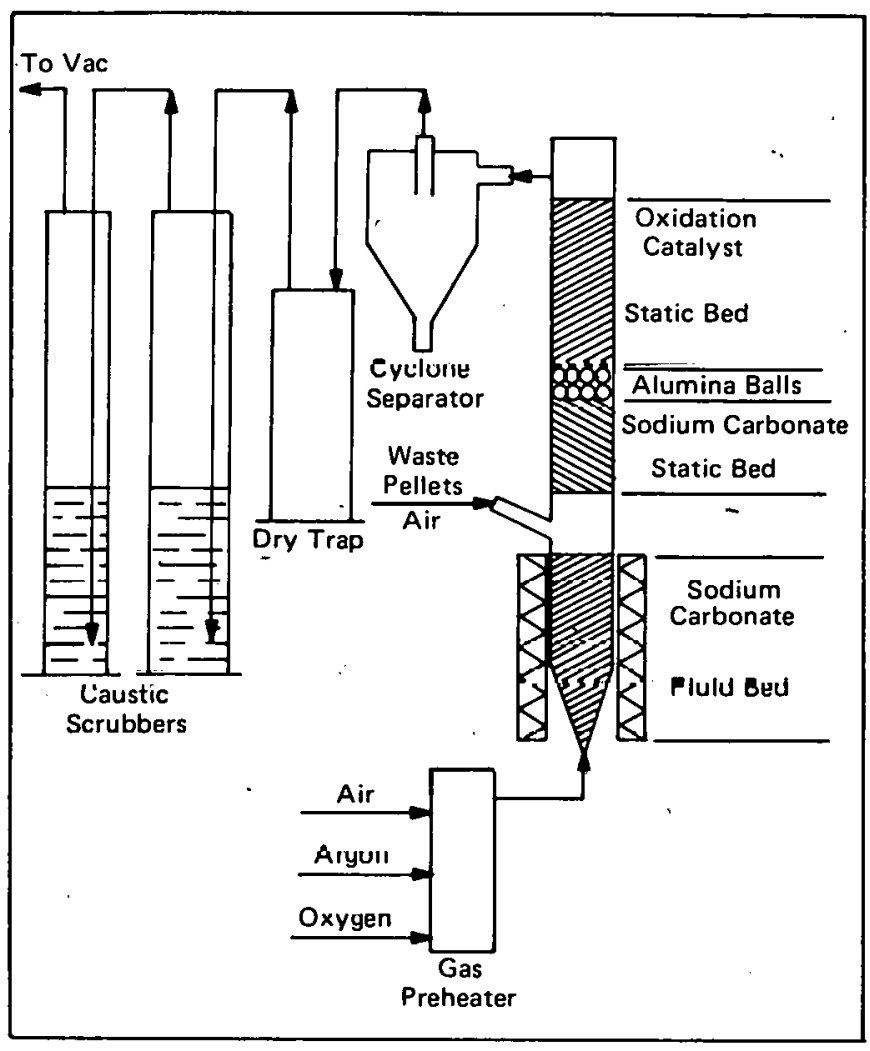

Figure 2. Laboratory Fluid Bed Incineration System No. 2.

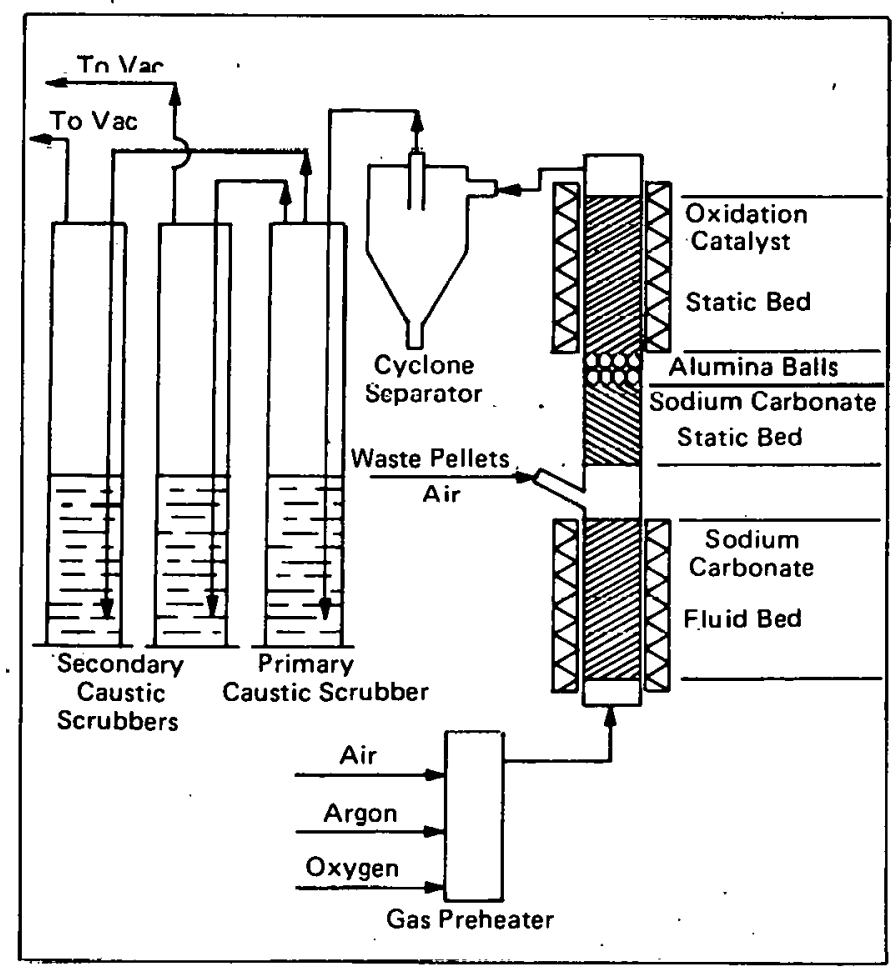


oxygen gas mixtures for bed fluidization. The caustic scrubbing system consisted of two 2,000-ml glass cylinders partially filled with one-half-inch polyethylene Raschig rings and one percent $\mathrm{NaOH}$ solution. Most incineration tests were made in an equipment array similar to that illustrated in Figure 2.

Figure 3 shows the final design refinements which were achieved during this study. A new quartz incinerator vessel was fabricated. It featured a 100-mesh gas-distribution screen for improved bed fluidization. The oxidation catalyst bed was enclosed in a furnace for improved temperature control and off-gas combustion efficiency. Another caustic scrubber vessel was added and offgas piping was modified to create a primary and secondary scrubbing system to guard against the loss of $\mathrm{HCl}$ from the system. This design was utilized for the last five incineration runs of this study.

\section{Incineration Procedure}

Test procedures varied throughout the study because emphasis was shifted from one-to-a nother of the various aspects of incineration. The earlier runs centered on the mechanics of fluid bed incineration; therefore, the successful decomposition of waste pellets in a fluidized bed was the major consideration. As seen in Figure 1, no $\mathrm{Na}_{2} \mathrm{CO}_{3}$ for $\mathrm{HCl}$ neutralization or oxidation catalyst for off-gas combustion was used in the early runs. Air was metered through a bed of heated one-quarter-inchdiameter alumina balls for preheating and gas distribution. The heated air was used to fluidize a bed of alumina granules. When a bed temperature of 600 to $650^{\circ} \mathrm{C}$ was reached, waste pellets were dropped in the top of the disengagement section for decomposition in the fluidized alumina bed. Decomposition tars and soot were retained in the dry trap and caustic scrubber. A propane-oxygen flame was introduced above the fluid bed in several runs in an attempt to burn the waste decomposition gases.

After the elementary principles of waste decomposition in a fluidized bed were studied, the emphasis shifted to the goals of complete $\mathrm{HCl}$ neutralization and cleanup of the off-gas stream. Consequently, the equipment shown in Figures 2 and 3 was substituted and procedures were modified to achieve these goals. Air or argon-oxygen gas mixtures were metered through a Chromalox preheater to aid in maintaining an operating temperature of $500^{\circ} \mathrm{C}$ within a fluidized bed of $\mathrm{Na}_{2} \mathrm{CO}_{3}$. Waste pellets and combustion air were introduced through a side port directly above the fluidized bed. The air and decomposition gases were drawn through the system by vacuum applied to the scrubbers. The decomposition gases were passed through a static bed of $\mathrm{Na}_{2} \mathrm{CO}_{3}$ in an effort to react any $\mathrm{HCl}$ gas that might escape from the fluidized $\mathrm{Na}_{2} \mathrm{CO}_{3}$ bed. The flow continued into a bed of oxidation catalyst to promote combustion of the waste decomposition gas. Air drawn in the side inlet provided additional oxygen for the combustion within the catalyst bed. When the cyclone separator proved reasonably successful in removing the small amounts of solids that escaped the incinerator, the use of a dry trap was discontinued. The off-gas was then drawn through the cyclone into the scrubbing system. In the final scrubber design, all the off-gas passed through a dip tube to the bottom of the first scrubbing vessel. After a thorough mixing with caustic solution in the Raschig ring-filled column, the stream was split as it left the vessel. The split gas streams were then drawn through two identical secondary scrubber vessels into the house vacuum system.

\section{Analytical Procedure}

The chloride present in the waste off-gases would come from the polyvinyl chloride (PVC) sheet material in the waste. Samples of the PVC plastisol used for bags and sheeting at the Rocky Flats Plant were analyzed by neutron activation methods and found to have an average concentration of $36.0 \%$ chloride. The amount of additives present, chiefly dioctyl-phthalate plasticizer, was determined with infrared spectroscopy to be $36.5 \%$ by weight. Calculation based on the remainder being PVC polymer also gave a $36.0 \%$ chloride content. The $36.0 \%$ chloride result was then used to calculate the weight of chloride present in batches of pelletized waste material.

The calculated chloride content could not be used as easily when the large scale pelletizer was used 
with machine shredded waste. The feed into the shredder was not closely controlled as to weight of various waste components and a method was needed to determine the average chloride content of these pellets when burned in an experimental run. The method finally developed was to place about $20 \mathrm{~g}$ of pellets in the bottom of a $200-\mathrm{ml}$ crucible, cover with powdered $\mathrm{Na}_{2} \mathrm{CO}_{3}$, and heat the crucible in a $600^{\circ} \mathrm{C}$ muffle furnace for 3 hours. The residue in the crucible was then dissolved in hot water and the solution analyzed for chloride content. Chloride in solutions is determined by the SCN titration method.

A typical, feed pellet analysis is given in Table 3. About $4 \mathrm{~kg}$ of typical waste that had been shredded in a shredder test was pelletized in the large pelletizer. 'I'hree grab samples were taken and the chloride determined. The spread in the results was close enough to warrant confidence in being able to calculate the amount of chloride fed to the reactor.

Table 3. Typical Feed Pellet Analysis.

\begin{tabular}{|c|c|c|c|}
\hline $\begin{array}{l}\text { Pellet Weight } \\
\text { (g) }\end{array}$ & $\begin{array}{l}\text { Chloride Found } \\
\text { (g) }\end{array}$ & & $\begin{array}{c}\text { Chloride } \\
\text { (wt\%) }\end{array}$ \\
\hline 27.97 & b.U6 & & 21.66 \\
\hline 24.30 & 3.22 & & 21.48 \\
\hline \multirow[t]{2}{*}{23.35} & 5.23 & & 22.40 \\
\hline & & Average & 21.85 \\
\hline
\end{tabular}

After the completion of a run, the chief interest has been the amount of chloride retained in the fluid bed, the secondary bed, the catalyst, and the scrubber. In several early runs the entire offgas system was washed and the solution analyzed for chloride. In all cases, the amount of chloride recovered was $<0.01 \%$ and the procedure of washing the glassware for chloride recovery was discontinued. Ash content of the bed materials was also determined as a measure of the weight reduction obtained on the incinerated waste. Off-gases were analyzed for determination of after-burner efficiency.

The material from both the fluid and secondary beds is essentially the same; mostly $\mathrm{Na}_{2} \mathrm{CO}_{3}$ with admixed $\mathrm{NaCl}$ and carbonized ash. The bed material was thoroughly mixed, and three weighed samples of approximately $25 \mathrm{~g}$ each were dissolved in hot water, held at near-boiling for about 3 hours, and the solution was filtered. A total of $250 \mathrm{ml}$ of water leach solution was collected for each sample; at this point all the residue was in the weighed filter paper. Solutions were analyzed for chloride and the dried filter paper was weighed to determine ash content.

The catalyst was removed from the chamber and leached with water. Chloride content of the leach solution was determined and the catalyst regenerated by heating at $800^{\circ} \mathrm{C}$ in air.

The scrubber solution was brought to a known volume and the chloride content determined. The lower chloride amounts in this solution and on the catalyst leach were obtained using the specific ion electrode method.

Off-gases were sampled by attaching an evacuated $10-\mathrm{cm}$ gas cell to the off-gas line and drawing the sample into the cell. The contained gases were then analyzed by infrared spectrophotometry. The amount of hydrocarbons that was not being oxidized by the after-burner was used to evaluate the effectiveness of various catalyst which was tried. Sotme of the catalyst produced a higher $\mathrm{CO}: \mathrm{CO}_{2}$ ratio than others; increasing the amount of added air to the catalyst chamber did not always eliminate this.

There have been no chlorinated hydrocarbons detected in the off-gases. Besides the infrared gas analysis, a part of the gas stream was pulled through $\mathrm{a} \mathrm{CCl}_{4}$ scrubber during some of the runs. No other chlorinated compounds were found in the $\mathrm{CCl}_{4}$ solutions by infrared analysis.

\section{DISCUSSION}

\section{$\mathrm{HCl}$ Neutralization}

One major objective of this study was to evaluate the effectiveness of neutralization of $\mathrm{HCl}$ gas produced by the decomposition of polyvinyl chloride waste material. Previous work by Dow Chemical Company ${ }^{2}$ suggested using $\mathrm{Na}_{2} \mathrm{CO}_{3}$ for neutralization by the following reaction.

$$
2 \mathrm{HCl}+\mathrm{Na}_{2} \mathrm{CO}_{3} \rightarrow 2 \mathrm{NaCl}+\mathrm{CO}_{2}+\mathrm{H}_{2} \mathrm{O}
$$


Three methods to utilize $\mathrm{Na}_{2} \mathrm{CO}_{3}$ for this purpose were evaluated during this investigation. They were as follows:

1. Pelletization of $\mathrm{Na}_{2} \mathrm{CO}_{3}$ and combustible wastes to ensure intimate contact during decomposition.

2. Decomposition of waste pellets in a fluidized bed of $\mathrm{Na}_{2} \mathrm{CO}_{3}$ granules.

3. Decomposition of waste pellets in an unreactive fluid bed material, then passing the resulting gases through a static bed of $\mathrm{Na}_{2} \mathrm{CO}_{3}$ for neutralization.

Each of the methods offered advantages, but each proved to be only partially successful alone.

Typical neutralization results obtained by these three separate methods are illustrated in Tables 4 , 5 , and 6 . The degree of neutralization that was obtained by each method was surprisingly similar, with each of the three falling within a range of 45 to $55 \%$ chloride retention. When it became obvious that no single method could achieve $100 \%$ neutralization under present conditions, combinations of the three methods were evaluated. Eventually the best results were attained by a combination of all three methods.

Table 4. $\mathrm{HCl}$ Neutralization Potential of $\mathrm{Na}_{2} \mathrm{CO}_{3}$ with $\mathrm{Al}_{2} \mathrm{O}_{3}$ Lower Bed-No Upper Bed- $\mathrm{Na}_{2} \mathrm{CO}_{3}$ Waste Pellets.

\section{CHLORIDE RFTENTION (wL\%)}

\begin{tabular}{|c|c|c|c|c|c|c|}
\hline Run No. & $\begin{array}{c}\text { Total } \\
\text { Recovery }\end{array}$ & $\begin{array}{l}\text { Lower } \\
\text { Bed }\end{array}$ & $\begin{array}{l}\text { Upper } \\
\text { Bed }\end{array}$ & $\begin{array}{c}\text { Catalyst } \\
\text { Bed }\end{array}$ & Scrubber & Lost \\
\hline 25 & 88.0 & 46.6 & $\begin{array}{l}\text { None } \\
\text { Used }\end{array}$ & 24.8 & 16.6 & 12.0 \\
\hline
\end{tabular}

Table 5. $\mathrm{HCl}$ Neutralization Potential of $\mathrm{Na}_{2} \mathrm{CO}_{3}$ with $\mathrm{Na}_{2} \mathrm{CO}_{3}$ Lower Bed-No Upper Bed-Non-Na $\mathrm{NO}_{3}$ Waste Pellets.

\begin{tabular}{lllllll}
\multicolumn{6}{c}{ CHLORIDE RETENTION (wt\%) } \\
Run No. & $\begin{array}{c}\text { Total } \\
\text { Rerovery }\end{array}$ & $\begin{array}{c}\text { Lower } \\
\text { Berd }\end{array}$ & $\begin{array}{c}\text { Upper } \\
\text { Berd }\end{array}$ & $\begin{array}{c}\text { Catalyst } \\
\text { Bed }\end{array}$ & Scrubber & Lost \\
\hline 60.6 & 49.4 & $\begin{array}{c}\text { None } \\
\text { Used }\end{array}$ & No data & 11.2 & 39.4
\end{tabular}

Table 6. $\mathrm{HCl}$ Neutralization Potential of $\mathrm{Na}_{2} \mathrm{CO}_{3}$ with $\mathrm{Al}_{2} \mathrm{O}_{3}$ Bed- $\mathrm{Na}_{2} \mathrm{CO}_{3}$ Upper Bed-Non-Na $\mathrm{CO}_{3}$ Waste Pellets.

$$
\text { CHLORIDE RETENTION (wt\%) }
$$

\begin{tabular}{|c|c|c|c|c|c|c|}
\hline No. & $\begin{array}{l}\text { Total } \\
\text { Recovery }\end{array}$ & $\begin{array}{l}\text { Lower } \\
\text { Bed }\end{array}$ & $\begin{array}{l}\text { Upper } \\
\text { Bed }\end{array}$ & $\begin{array}{c}\text { Catalyst } \\
\text { Bed }\end{array}$ & Scrubber & Lost \\
\hline 18 & 73.8 & 0 & 55.4 & No data & 18.4 & 26.2 \\
\hline
\end{tabular}

Tabulated in Table 7 are the results obtained by the use of two of the neutralization methodsfluidized $\mathrm{Na}_{2} \mathrm{CO}_{3}$ bed and static upper $\mathrm{Na}_{2} \mathrm{CO}_{3}$ bed. An average of $90 \%$ of the $\mathrm{HCl}$ produced was retained in these two beds. In the runs shown in Table $8, \mathrm{Na}_{2} \mathrm{CO}_{3}$ was added to the waste pellets to incorporate all three neutralization methods. In this series an average of $92 \%$ of the $\mathrm{HCl}$ generated was retained in the two $\mathrm{Na}_{2} \mathrm{CO}_{3}$ beds. More significant is the $11 \%$ average increase in the amount of $\mathrm{HCl}$ retained in the lower bed. This appears to be the direct result of the use of $\mathrm{Na}_{2} \mathrm{CO}_{3}$ feed pellets. These neutralization results in this table were the best achieved during the study.

Table 7. $\mathrm{HCl}$ Neutralization Obtained with $\mathrm{Non}-\mathrm{Na}_{2} \mathrm{CO}_{3}$ Waste Pellets (Fluidized $\mathrm{Na}_{2} \mathrm{CO}_{3}$ Lower BedStatic $\mathrm{Na}_{2} \mathrm{CO}_{3}$ Upper Bed).

\section{CHLORIDE RETENTION (wt\%)}

\begin{tabular}{|c|c|c|c|c|c|c|}
\hline Run No. & $\begin{array}{c}\text { lotal } \\
\text { Recovery }\end{array}$ & $\begin{array}{l}\text { Lower } \\
\text { Bed }\end{array}$ & $\begin{array}{c}\text { Upper } \\
\text { Bed }\end{array}$ & $\begin{array}{l}\text { Catalyst } \\
\text { Bed }\end{array}$ & Scrubber & Lost \\
\hline 20 & 92.0 & 84.3 & 7.1 & Nó data & 0.6 & 8.0 \\
\hline 21. & 90.8 & 743 & 1.5 .3 & No data & 1.2 & 9.2 \\
\hline 22 & 90.5 & 76.6 & 12.6 & No data & 1.3 & 9.5 \\
\hline Average & 91.1 & 78.4 & 11.6 & - & 1.0 & 8.9 \\
\hline
\end{tabular}

Table 8. $\mathrm{HCl}$ Neutralization Obtained with $\mathrm{Na}_{2} \mathrm{CO}_{3}$ Wạste Pellets (Fluidized $\mathrm{Na}_{2} \mathrm{CO}_{3}$ Lower Bed-Static $\mathrm{Na}_{2} \mathrm{CO}_{3}$ Upper Bed).

CHLORIDE RETENTION (wt\%)

\begin{tabular}{|c|c|c|c|c|c|c|}
\hline Run No. & $\begin{array}{c}\text { Total } \\
\text { Recovery }\end{array}$ & $\begin{array}{c}\text { Lower } \\
\text { Bed }\end{array}$ & $\begin{array}{c}\text { Upper } \\
\text { Bed } \\
\end{array}$ & $\begin{array}{c}\text { Catalyst } \\
\text { Bed } \\
\end{array}$ & Scrubber & Lost \\
\hline 19 & 97.2 & 90.9 & 5.8 & No data & 0.5 & 2.8 \\
\hline 26 & 95.3 & 88.7 & 5.9 & 0.4 & 0.3 & 4.7 \\
\hline 27 & 96.6 & 91.6 & 1.8 & 1.0 & 2.2 & 3.4 \\
\hline 28 & 94.8 & 87.2 & 0.2 & 7.0 & 0.4 & 5.2 \\
\hline 29 & 91.8 & 87.8 & 1.4 & 0.3 & 2.3 & 0.2 \\
\hline Average & 95.1 & 89.2 & 3.0 & 2.2 & 1.1 & 4.9 \\
\hline
\end{tabular}


Neutralization efficiency of a $\mathrm{Na}_{2} \mathrm{CO}_{3}$ bed was expected to decrease as the $\mathrm{NaCl}$ concentration of the bed increased. To test this theory, one run was stopped to analyze the chloride content of the $\mathrm{Na}_{2} \mathrm{CO}_{3}$ beds, then continued to evaluate extended run efficiency. The results of this run are shown in Table 9. As expected, the percent of chloride retained in the lower bed decreased by approximately $6 \%$ during the second half of the run when $22 \%$ of the bed had converted to $\mathrm{NaCl}$. The upper $\mathrm{Na}_{2} \mathrm{CO}_{3}$ bed did retain more chloride in the second half of the run, however. These results point to the conclusion that an upper bed will more likely be necessary in extended runs to achieve the best possible chloride reterition.

Table 9. Effect of Fluid Bed $\mathrm{NaCl}$ Concentration on $\mathrm{HCl}$ Neutralization $\left(\mathrm{Na}_{2} \mathrm{CO}_{3}\right.$ Lower Bed $-\mathrm{Na}_{2} \mathrm{CO}_{3}$ Upper Bed - Non- $\mathrm{Na}_{2} \mathrm{CO}_{3}$ Lead Waste Pellets.

CIILORIDE RETEN'I'IUN (wt\%)

\begin{tabular}{|c|c|c|c|c|c|c|c|}
\hline $\begin{array}{l}\text { Run } \\
\text { No. }\end{array}$ & $\begin{array}{c}\mathrm{Na}_{2} \mathrm{CO}_{3} \\
\text { Utilization } \\
(\%) \\
\end{array}$ & $\begin{array}{c}\text { Total } \\
\text { Recovery } \\
\end{array}$ & $\begin{array}{c}\text { Lower } \\
\text { Bed } \\
\end{array}$ & $\begin{array}{c}\text { Upper } \\
\text { Bed } \\
\end{array}$ & $\begin{array}{c}\text { Catalyst } \\
\text { Bed } \\
\end{array}$ & Scrubber & Lost \\
\hline $24 a$ & $\begin{array}{ll}0 & -13.0\end{array}$ & 96.9 & 72.8 & 20.2 & 2.7 & 1.2 & 3.1 \\
\hline $24 b$ & $13.0-22.2$ & 95.5 & 66.6 & 23.1 & 1.5 & 4.3 & 4.5 \\
\hline
\end{tabular}

Two runs were made to evaluate the addition of water vapor as a means of enhancing the $\mathrm{HCl}$ $\mathrm{Na}_{2} \mathrm{CO}_{3}$ reaction. In Run 28, approximately 50 milliliters of water were added to the fluidization gas by bubbling it through a water trap. In Run 29, water was metered directly into the fluidization gas preheater at an average rate of 10 milliliters per minute. Approximately 800 milliliters was added during the entire run, in which 110 grams of waste pellets was decomposed. Table 8 shows that no significant increase in $\mathrm{HCl}$ neutralization was affected by these procedures. However, poor bed fluidization appeared to be an adverse effect of the water vapor, even though bed temperature was maintained at $500^{\circ} \mathrm{C}$ during each run.

Waste pellet feeding rates were examined as another variable that might affect $\mathrm{HCl}$ neutralization. Feed rates were restricted by one major factor-that of temperature increase in the catalyst bed as the result of combustion of hydrocarbons in the flue gas. The present incinerator had no refinements for cooling the catalyst section; therefore, it was necessary to curtail feeding when temperatures within the catalyst bed exceeded $800^{\circ} \mathrm{C}$. The average feed rates for the runs shown in Tables 7 and 8 varied from 1.36 to 2.71 grams per minute.

There was no discernible relationship between feed rates and $\mathrm{HCl}$ neutralization within this range. The best $\mathrm{HCl}$ neutralization accomplished during the study occurred in Run 19, in which the average feed rate was 2.14 grams per minute.

Evaluations of $\mathrm{HCl}$ neutralization runs were hindered by one obstacle throughout the course of the investigation. This was the constant problem of $\mathrm{HCl}$ unaccounted for in each run. In early runs. $\mathrm{HCl}$ losses ran as high as $50 \%$, but this figure was gradually lowered by refinements in equipment, procedures, and analytical methods. Still, an average of $6.4 \%$ of the $\mathrm{HCl}$ produced in the 12 most efficient. runs was not accounted for hy most diligent analytical procedurcs. Because of the consistency of the losses, analytical errors were ruled out as a major cause. Since $\mathrm{HCl}$ can be driven from polyvinyl chloride at relatively low temperatures, a loss of portion of the $\mathrm{HCl}$ during the waste pelletizing process seemed a likely assunupliun. To lest this theory, à rün was made in which only unpelletized polyvinyl chloride was decomposed in the incinerator. Only $91.3 \%$ of the known chloride released in the run was accuunted for in the $\mathrm{Na}_{2} \mathrm{CO}_{3}$ beds and scrubber system. The missing $8.7 \%$ fell within the average loss range that had been experienced in previous runs. The possibility of loss of chloride as a chlorinated hydrocarbon aerosol was considered but never proven during the study.

\section{Effects of Fluidization Gas Composition on Ash Generation}

Waste decomposition was accomplished by pyrolysis in the fluid bed incinerator. Pyrolysis proved superior to combustion for two reasons. First, no refractory oxides were produced; and second, relatively low bed temperatures permitted the use of $\mathrm{Na}_{2} \mathrm{CO}_{3}$ for $\mathrm{HCl}$ neutralization. Subsequently, the oxygen concentration of the fluidization gas was limited to prevent above-bed burning in the reactor. Argon or argon-oxygen mixtures were most often used for fluidization, but marginal 
results were also obtained by the use of air for fluidization purposes. There was no apparent difference in bed fluidization as the result of the use of any particular gas or gas mixture.

Carbon residue or ash was deposited in the incinerator beds during each run. The materials were analyzed for ash content after each run. The ash retention of the runs made with argon fluidization gas are shown in Table 10. An average of $9.47 \%$ of the waste material decomposed in these runs was retained in the bed residues. In Table 11 , this figure was reduced to $5.3 \%$ for a series of runs in which various argon-oxygen mixtures were used for fluidization. The $44 \%$ decrease in ash generation was accomplished without above-bed burning or open-flame burning of pyrolysis gases before they reached the catalyst section of the incinerator. Two runs in which air was used for fluidization produced an average ash residue of only $3.87 \%$. The results of these runs are presented in Table 12.

Although pure-air fluidization-gas reduced the ash, on several occasions it promoted above-bed burning

Table 10. Ash Retention in $\mathrm{Na}_{2} \mathrm{CO}_{3}$ Beds with Argon Fluidization Gas.

\begin{tabular}{|c|c|c|c|c|}
\hline \multirow[b]{2}{*}{ Run No. } & \multirow{2}{*}{$\begin{array}{l}\text { Fluidization Gas } \\
\text { (per cent. } \mathrm{O}_{2} \text { ) }\end{array}$} & \multicolumn{3}{|c|}{ WASTE RETAINED (wt\%) } \\
\hline & & Lower Bed & Upper Bed & Total \\
\hline 10 & 0 & 8.35 & None Used & 8.35 \\
\hline 16 & 0 & 7.01 & None Used & 7.01 \\
\hline 19 & 0 & 7.43 & 4.42 & 11.85 \\
\hline 20 & 0 & 8.84 & 1.81 & 10.65 \\
\hline Average & 0 & 7.91 & 3.12 & 9.47 \\
\hline
\end{tabular}

Table 11. Ash Retention in $\mathrm{Na}_{2} \mathrm{CO}_{3}$ Beds with ArgonOxygen Fluidization Gas.

\begin{tabular}{|c|c|c|c|c|}
\hline \multirow[b]{2}{*}{ Run No. } & \multirow{2}{*}{$\begin{array}{l}\text { Fluidization Gas } \\
\text { (percent } \mathrm{O}_{2} \text { ) }\end{array}$} & \multicolumn{3}{|c|}{ WASTE RETAINED (wt\%) } \\
\hline & & Lower Bed & Upper Bed & Total \\
\hline 13 & 11.35 & 1.03 & None Used & 1.03 \\
\hline 14 & 6.23 & 3.22 & None Used & 3.22 \\
\hline 21 & 5.27 & 1.75 & 2.14 & 3.89 \\
\hline 22 & 8.91 & 1.75 & 4.00 & 5.75 \\
\hline $24 a, b$ & 9.55 & 4.93 & 1.16 & 6.09 \\
\hline 26 & 6.94 & 3.91 & 0.55 & 4.46 \\
\hline$? 7$ & $9.0 n$ & 6.09 & 7.20 & 13.29 \\
\hline 28 & 7.54 & 3.87 & 0.65 & 4.52 \\
\hline Average & 8.10 & 3.32 & 2.62 & 5.28 \\
\hline
\end{tabular}

Table 12. Ash Retention in $\mathrm{Na}_{2} \mathrm{CO}_{3}$ Beds with Air Fluidization Gas.

\begin{tabular}{|c|c|c|c|c|}
\hline \multirow{2}{*}{ Run No. } & \multirow{2}{*}{$\begin{array}{l}\text { Fluidization Gas } \\
\text { (percent } \mathrm{O}_{2} \text { ) }\end{array}$} & \multicolumn{3}{|c|}{ WASTE RETAINED (wt\%) } \\
\hline & & Lower Bed & Upper Bed & Total \\
\hline 23 & 21.0 & 2.62 & 0.71 & 3.33 \\
\hline 29 & 21.0 & 3.56 & 0.84 & 4.40 \\
\hline Average & 21.0 & 3.09 & 0.78 & 3.87 \\
\hline
\end{tabular}

or open-flame burning in the reactor. Heat produced by excessive combustion cannot be tolerated in the fluid bed; therefore, pure air was considered unsatisfactory for fluidization. It appears that an oxygen concentration somewhere between 10 and $15 \%$ may be optimum, but more work in this area is needed to fully investigate this aspect of fluid bed incineration.

\section{Leaded Glove Incineration}

Tests at incinerator manufacturer facilities indicated a potential problem with incineration of leaded gloves because of the generation of lead metal within the incinerator.

Only minor quantities of leaded gloves have been burned in the Rocky Flats incinerator because of the problems of processing the lead residues. Three runs were made during this study to determine whether or not leaded gloves could be processed by fluid bed incineration. The results of these runs indicate that, with additional work, the process could more than likely be adapted for this purpose.

The first two runs were conducted with waste pellets that contained approximately $5 \mathrm{wt} \%$ leaded gloves without $\mathrm{Na}_{2} \mathrm{CO}_{3}$. The complete composition of these pellets is shown in Table 2. A lower fluidized bed of $\mathrm{Na}_{2} \mathrm{CO}_{3}$ and an upper static bed of $\mathrm{Na}_{2} \mathrm{CO}_{3}$ were utilized for $\mathrm{HCl}$ neutralization. After 207 grams of waste had been decomposed, the first run was stopped for inspection of the fluid bed miterial.

The $\mathrm{Na}_{2} \mathrm{CO}_{3}$ was in good condition with no visible lead metal deposits. It was returned to the incinerator for the second run. The second run went well until approximately 200 grams of waste had been 
processed. At this point, fluidization was lost and could not be regained by increased gas flow. When the reactor was disassembled, a large clinker was found to be obstructing the fluidization gas inlet. The clinker had caused the quartz tube to crack during the cooling process. The clinker material was hard and dense, and analyzed to be primarily $2 \mathrm{PbCO}_{3}, \mathrm{~Pb}(\mathrm{OH})_{2}$. No lead metal was visible in the bed material.

The third run was made with a fluidized bed of $\mathrm{Al}_{2} \mathrm{O}_{3}$ and finely chopped pieces of leaded gloves. Air was used to fluidize the bed, and a bed temperature of about $500^{\circ} \mathrm{C}$ was maintained. Fluidization was excellent throughout; the bed material was free of lead metal at the completion of the run. The various parts of the incinerator system were analyzed for the chloride retained from the $7.6 \%$ chloride content of the gloves.

Total recovery of chloride was only $47 \%$ of the amount added. A relatively large amount of material had been collected in the cyclone and this was placed in a $800^{\circ} \mathrm{C}$ furnace to burn off the carbon prior to identification of the residue.

White fumes were observed coming off the material; a sample was condensed on a cold test tube and submitted for analysis. The material was identified by $\mathrm{x}$-ray analysis as $\mathrm{PbCl}_{2}$. This would account for the low chloride recovery on the run. The $\mathrm{PbCl}_{2}$ deposited in the cooler parts of the system as well as in the cyclone. This would present no problem in large scale work, as $\mathrm{PbCl}_{2}$ can be either scrubbed or filtered from the off-gases

\section{Oxidation Catalysts}

Open-flame after-burning of incinerator flue gas required 1,000 to $1,200^{\circ} \mathrm{C}$ for complete combustion of trace hydrocarbon. The two major advantages to be realized by the use of a catalytic after-burner are as follows:

1. The minimum temperature required for the catalytic after-burner is about 400 to $600^{\circ} \mathrm{C}$. This lower temperature will allow a wider variety of materials which would be satisfactory for construction of the after-burner. It would not be necessary to use refractory lined equipment which involves the costly operation of re-bricking. and it would also eliminate the costly and difficult operation of recovering plutonium from the used refractories.

2. Oxidation catalysts are quite effective in obtaining complete combustion of hydrocarbons even at reduced oxygen concentrations. This would eliminate the need for a large excess of oxygen in the after-burner, thereby decreasing the volume of flue gas which has to be cleaned and ultimately passed through HEPA filtration prior to release to the atmospherc. The catalysts also make possible an incincration system in which the gases would not have to be in the normal flammable or explosive concentrations.

An oxidation satalyst, to he satisfactory for use in the incinerator after-burner, should exhibit good resistance to $\mathrm{HCl}$ attack, low oxidation temperature requirements, and good oxidation efficiency with the hydrocarbons contained in the flue gas stream. To aid in selecting a suitable oxidation catalyst, a series of test3 was made which consisted of contacting the catalysts with a humid $\mathrm{HCl}$ gas stream at $500^{\circ} \mathrm{C}$ for 2 hours and then evaluating their oxidation efficiencies with a methane-air mixture. The following six catalysts were examined for their resistance to $\mathrm{HCl}$ attack and for their nxidation efficiency:

1. Shell 105X-Shell Chemical Company, oneeighth-inch-diameter pellets, $\mathrm{Fe}_{2} \mathrm{O}_{3}$ with $21.7 \%$ potassium as a promoter.

2. Zeolon $200 \mathrm{H}-$ Union Carbide, Norton Chemical Process Division, one-sixteenth-inch-diameter pellets, $10 \%$ silicone oxide on a sodium (1\%)alumina support.

3. ZR-0304T-Harshaw Chemical Company, oneeighth-inch-diameter pellets, zirconium oxide $(98 \%)$ mixed with alumina $(2 \%)$.

4. CR-0211T-Harshaw Chemical Company, $5 / 32$-inch-diameter pellets, chromium oxide on alumina. 
5. Linde 13X molecular sieves-Union Carbide Company, Norton Chemical Process Division, one-sixteenth-inch-diameter pellets, (as shipped $\mathrm{H}_{2} \mathrm{O} 1.5$ wt\%).

6. Grace CAT 908-Davison Chemical Company, one-quarter-inch-diameter balls, copper and magnesium oxides with alumina base.

Presented in Table 13 are oxidation efficiencies of the catalysts as a function of oxidation run time. Three of the catalysts; Harshaw CR-0211T, Linde 13X molecular sieve, and Grace CAT 908 exhibited essentially $100 \%$ efficiencies from the beginning. The Linde 13X molecular sieve gained weight during $\mathrm{HCl}$ treatment, indicating $\mathrm{HCl}$ adsorption. It lost weight during oxidation tests, indicating that the $\mathrm{HCl}$ was being desorbed. The $\mathrm{HCl}$ did not appear to harm the catalysts' oxidation characteristics as evidenced by the $100 \%$ efficiency. The Grace CAT 908 exhibited a large weight loss during oxidation tests without a similar weight gain during $\mathrm{HCl}$ treatment; indicating that part of the catalyst was being driven off as a chloride compound. The other catalysts exhibited a gradual increase in efficiency as a function of time. This indicates that they were attacked by the $\mathrm{HCl}$ but are regenerated to some extent by the oxidation conditions.

The efficiency of methane oxidation as a function of reaction temperature for the same catalysts is presented in Table 14. The Grace CAT 908 and the Harshaw CR-0211 T exhibited essentially $100 \%$ efficiency at $400^{\circ} \mathrm{C}$. The Linde $13 \mathrm{X}$ molecular sieves and the Harshaw ZR-0304T required $500^{\circ} \mathrm{C}$, and the Linde Zeolon $200 \mathrm{H}$ and the Shell $105 \mathrm{X}$ required about $600^{\circ} \mathrm{C}$ to obtain near $100 \%$ efficiency.

Table 13. Catalyst Oxidation Efficiencies (percent of methane oxidized).

\begin{tabular}{|c|c|c|c|c|c|c|}
\hline $\begin{array}{l}\text { lime } \\
(\mathrm{hr})\end{array}$ & $\begin{array}{c}\text { Shell } \\
\text { 10̈5X } \\
(\%) \\
\end{array}$ & $\begin{array}{c}\text { Zeolon } \\
200 \mathrm{H} \\
(\%) \\
\end{array}$ & $\begin{array}{c}\mathrm{ZR}-0304 \mathrm{~T} \\
(\%) \\
\end{array}$ & $\begin{array}{c}\text { CR-0211T } \\
(\%) \\
\end{array}$ & $\begin{array}{l}\text { Linde } \\
13 X \\
(\%) \\
\end{array}$ & $\begin{array}{c}\text { Grace CAT } \\
908 \\
(\%) \\
\end{array}$ \\
\hline .5 & 79.33 & 48.76 & 48.2 & 99.99 & 99.99 & 99.95 \\
\hline 1. & 93.89 & .57 .62 & 61.47 & 99.99 & 99.99 & 99.899 \\
\hline 1.5 & - & 59.89 & - & - & - & - \\
\hline 2. & 91.98 & 61.3 & .76 .12 & 99.97 & 99.99 & 99.99 \\
\hline 2.5 & $=$ & 74.56 & - & - & -. & - \\
\hline 3. & - & - & 99.98 & 99.99 & 99.99 & 99.99 \\
\hline 3.5 & - & - & 99.99 & - & - & - \\
\hline
\end{tabular}

Table 14. Catalyst Oxidation Temperature Requirements.

\begin{tabular}{|c|c|c|c|c|c|c|}
\hline $\begin{array}{l}\text { Temp. } \\
\text { ( } \mathrm{C})\end{array}$ & $\begin{array}{l}\text { Shell } \\
105 X \\
\% \text { eff. }\end{array}$ & $\begin{array}{c}\text { Linde } \\
\text { Zeolon } \\
200 \mathrm{H} \\
\% \text { eff. } \\
\end{array}$ & $\begin{array}{c}\text { Harshaw } \\
\text { ZR-0304T } \\
\text { \% eff. } \\
\end{array}$ & $\begin{array}{c}\text { Harshaw } \\
\text { CR-0211T } \\
\text { \% eff. }\end{array}$ & $\begin{array}{c}\text { Linde } \\
13 \mathrm{X} \\
\text { Sieves } \\
\% \text { eff. } \\
\end{array}$ & $\begin{array}{c}\text { Grace CAT } \\
908 \\
\% \text { eff. } \\
\end{array}$ \\
\hline 200 & 0 & 0.89 & 0 & 0 & 0 & 0 \\
\hline 300 & 0 . & 6.14 & 0 & 13.5 & 0 & 0 \\
\hline 400 & 6.72 & 4.8 & 33.59 & 99.95 & 0 & 99.3 \\
\hline 500 & 66.67 & 59.96 & 99.99 & 99.99 & 99.99 & 99.88 \\
\hline 600 & 97.24 & 99.96 & 99.99 & 99.99 & 99.445 & 99.89 \\
\hline 700 & - & 99.91 & - & - & - & - \\
\hline
\end{tabular}

Of the catalysts tested, the Harshaw CR-0211T exhibited the best combination of resistance to $\mathrm{HCl}$ attack and good oxidation efficiency at a minimum temperature of $400^{\circ} \mathrm{C}$. The Linde $13 \mathrm{X}$ molecular sieves would probably be satisfactory at $500^{\circ} \mathrm{C}$ and the Linde Zeolon $200 \mathrm{H}$ would be acceptable if the minimum temperature of $600^{\circ} \mathrm{C}$ can be tolerated in the after-burner.

The latter two catalysts would probably require heating of the flue gas before entering the afterburner.

Three of the catalysts were used in the laboratory fluid bed incinerator: CR-0211T, Linde 13X, and Grace No. 908. In addition to these, the following two others were tested.

1. V-0301T-Harshaw Chemical Companyone-eighth-inch-diameter pellets, vanadium. dioxide $(86 \%)$ with alumina.

2. Mn-0201T-Harshaw Chemical Companyone-eighth-inch-diameter pellets, manganese dioxide (19\%) with alumina.

Of the catalysts used on the fluid bed incinerator, only the Harshaw CR-0211T and the Linde 13X molecular sieves functioned well. The other catalysts functioned well at the beginning, but appeared to lose efficiency with time. After prolonged use, they allowed tar to pass through the catalyst unreacted, and occasionally part of the decomposed catalyst was collected in the off-gas equipment. 


\section{Feed Preparation}

The residues will have to be converted to a form suitable for introduction into the fluid bed incinerator. The bulk waste has to be reduced in size so that it would not cause malfunction of fluidization of the granular sodium carbonate. The waste could be converted to a pellet by passing the waste mixture through a heated die whereby the plastic materials would become partially molten and hold the remaining materials together. All but one of the runs made on the laboratory reactor used waste material prepared by this method.

A pilot model of an extruder was fabricated which has a nominal capacity of about 5 to $10 \mathrm{lb} / \mathrm{hr}$. This unit consists of a 6-inch-diameter cylinder and piston which forces the waste material through a die that has 37 three-eighth-inch holes in it. The die is heated by 14 cal-rod heaters drawing 3,000 watts and is operated at about $175^{\circ} \mathrm{C}$. This is a batch operated unit. The cylinder is filled with a mixture of waste materials which is forced through the die by a 30 -ton hydraulic ram. The extrusions are cut to about one-inch lengths which have functioned well in the fluidized bed of sodium carbonate. These extrusions or pellets are normally introduced in the reactor by free fall. The major problem with the extruder is that it requires a reasonable mixture of plastic with the other waste materials. On a production basis, shredding of waste material may be required to obtain a suitable mixture for extrusion. If a charge of nonplastic and nonrubber is introduced, the unit will malfunction owing to plugging of the die. This can be cleared by excessive heating but it produces considerable smoke as the result of decomposition of the waste plug, which will pass through the die.

A series of shredding tests was performed to determine if suitable shredding equipment exists to handle our waste materials. Two drums of noncontaminated waste materials were sent to each of four shredder manufacturers. The composition of the waste materials in these drums is presented in Table 15.
Table 15. Composition of Waste Drums for Shredding Tests.

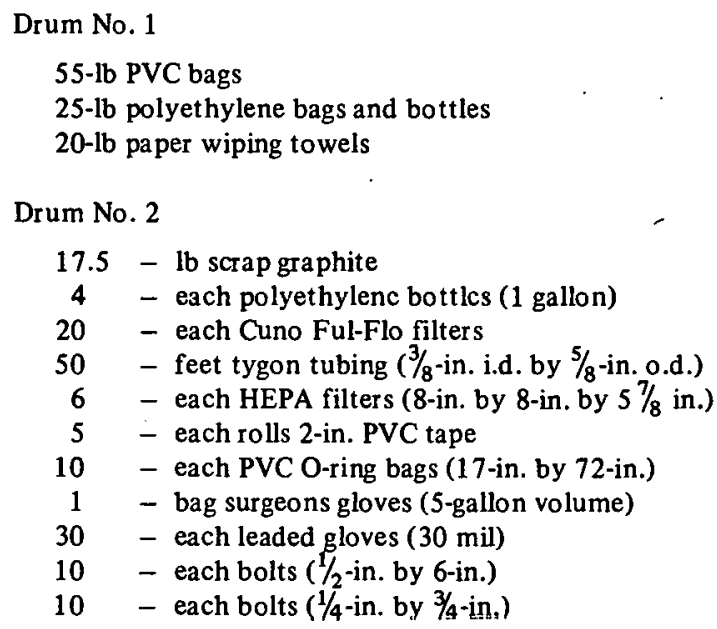

Tests of the following four types of equipment were conducted at the manufacturer's facilities:

1. A vertical-shaft hammer-mill with ring-type hammers. The shredded material was forced through an adjustable orifice ring between the rotating member and the stationary frame.

2. A horizontal-shaft hammer-mill with fixed hammers. The shredded material was forced through a heavy screen with about one-inchdiameter holes.

3. A rubber chopper. This is a low speed machine which cuts the material between rotating hammers or blades and stationary anvils. It then conveys the material and forces it through a stationary orifice plate. The material is cut again by rotating knives as it comes through the orifice plate.

4. A low speed shredder which cuts the material between cutters mounted on two parallel horizontal shafts which rotate at different speeds and in opposite directions. The cutters on one shaft intermesh with the cutters on the other shaft and the material is pulled into the machine by the teeth on the cutter.

The vertical-shaft hammer-mill is a large unit powered by a $100-h p$ drive and costs around $\$ 25,000$. It requires a floor space of about 6 -feet wide by 8 -feet long and about 11 -feet tall. It did a satisfactory job of shredding all the waste materials and worked best on brittle materials such as HEPA filters and graphite. The surgeon gloves 
were the most difficult for this machine and bordered on not being satisfactorily shredded. However, if these were shredded with other material, a better product size could be expected. This machine is undesirable from a nuclear safety point of view because it has many large cavities which could become filled with waste and could only be inspected by partial equipment disassembly. The machine was capable of accepting a charge of about 25 gallons without overloading. The capacity of the unit far exceeds our requirements. The 25-gallon charge will clear the machine in 3 to 4 minutes.

The horizontal-shaft hammer-mill was powered by a 50-hp motor. It did a satisfactory job of grinding the material but had considerable difficulty in handling the plastic sheet material. The plastic sheet or bags tended to wrap around the rotor, and on two occasions stalled the motor. The unit could only handle a charge of about 3 or 4 gallons without overloading. As with the other hammer mill, this unit did the best job on the brittle materials. The machine would also require partial disassembly for nuclear safety inspection. A larger machine was recommended which had a 150-hp drive and would cost about $\$ 12,000$. However, operation of this machine is considered unacceptable because of the wrapping of waste material around the rotor and the general undesirable performance.

The rubber chopper tested was powered by a 30-hp motor on the prebreaker and a 15-hp motor on the cutting knives. The pre-breaker consists of a series of hammers which rotate at about $20 \mathrm{rpm}$ and rough cuts the materials against some stationary anvils. These harrimers also convey and force the material through an orifice plate. The cutter knives rotate at about $400 \mathrm{rpm}$ and cut the material as it comes through the orifice plate. This machine is about 10-feet long, 5-feet wide, and about 4feet tall; cost is about $\$ 20,000$. This machine did a superior job of cutting the waste material compared to the other machines tested. It appeared to have sufficient power to do the job and at no time was overloaded. The graphite is not a satisfactory feed for this machine. The wood, plastic, paper, and rubber were ground satisfactorily. This machine can be easily inspected for nuclear safety without disassembly. The only major disadvantage to this machine is that it could be severely damaged by large tramp metal such as wrenches.

The low speed shredder was the only machine tested which physically could be placed in a glovebox type of operation. The others would probably have to be installed in a canyon or hot-cell type of operation.

It is a low speed type of cutter which has a reversal mechanism to protect it from over torque which could result from tramp metal entering the cutters. The first two drums were run through a machine powered by a 7.5 -hp drive. The unit appeared to do an acceptable job of shredding the waste material. The machine was under-powered and reversed itself many times during these tests. Another drum of paper, PVC, and polyethylene was sent for a second test. For this test, one-half of the cutters were replaced by blanks and the machine was set up with a 10-hp high-torque motor. The PVC had been the most difficult to shred in the first test. With this set-up, the machine performed satisfactorily on 100\% PVC and on any mixture of PVC, polyethylene, and paper. This unit will cost about $\$ 5,000$ and is available with a 6-week delivery time. Another advantage of this unit is that it can be visually inspected for nuclear safety without any disassembly.

\section{REFERENCES}

1. M. A. Thompson, Research and Ecology Semiannual Progress Report, USAEC RFP-1921-A, Rocky Flats Division, Dow Chemical U.S.A., August 30, 1972.

2. United States Patent No. 3,556,024,'January 19, 1971 , Dow Che mical Co., Midland, Michigan. 